\title{
Regioselective Synthesis of $\alpha$-Methyl 2-Methyleneglutarate via a Novel Lactonization-Elimination Rearrangement
}

\author{
David M. Bartley and James K. Coward ${ }^{\star}$ \\ Departments of Medicinal Chemistry and Chemistry, University of Michigan, Ann Arbor, Michigan \\ 48109-1055 jkcoward@umich.edu
}

\begin{abstract}
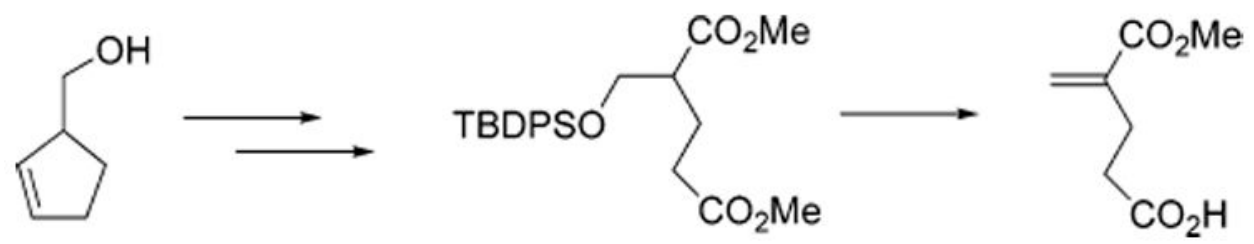

A facile route to the a-methyl ester of 2-methyleneglutarate via a three-step sequence from 3hydroxymethylcyclopentene is described. Regioselective formation of the monoacid from a diester precursor proceeds via a novel fluoride-mediated, tandem deprotection/rearrangement of $O$-silyl 2(hydroxymethyl)dimethylglutarate.
\end{abstract}

Acrylic acids and acrylate esters substituted at C-2 are synthetically useful intermediates, particularly in the synthesis of natural products, $1-3$ pseudopeptides, $4-6$ and polymers.7 Our interest in the design of phosphorus-containing pseudopeptides as inhibitors of ATPdependent ligases8,9 and $\mathrm{Zn}$ proteases 10 has led us to develop new routes to both the a- and $\gamma$-monoesters of 2-methyleneglutaric acid. As shown in Scheme 1, retrosynthetic analysis suggested that the desired pseudopeptide, 1, could possibly be obtained by either of two routes. These included the stereoselective conjugate addition of a nucleophilic organophosphorus synthon to the differentially protected a-methyleneglutarate, $\mathbf{2}$, bearing a chiral auxiliary (e.g., Evans' oxazolidinone).5 In our hands, the diastereoselectivity of this reaction was modest, 9 so the possible use of $\Delta^{2}$-cyclopentenylcarbinol, $\mathbf{4}$, as a glutarate surrogate leading to (2R)-2-(hydroxymethyl)glutaric acid, $\mathbf{3}$, was investigated

Racemic 4 (rac-4) and its sulfonate esters have been investigated as precursors of delocalized carbonium ions, leading to rearranged products on solvolysis.11 These authors reported a multistep, low-yielding synthesis of rac-4, which has been used by at least one other group but with no yields given.12 To synthesize pseudopeptide 1 with the desired stereochemistry ( $2 S, 2^{\prime} S$ ), a stereospecific synthesis of $\mathbf{3}$ was required which, in turn, required a substituted cyclopentene precursor, e.g., $\mathbf{4}$, of high stereochemical purity. The enantiomer of 4, (3R)-3- (hydroxymethyl)cyclopentene (ent-4), has been described by Maeda and Inouye.13 Thus, ent $\mathbf{4}$ was obtained from ethyl (2-oxo)cyclopentane carboxylate via an enzyme-catalyzed dynamic kinetic resolution to yield the (2R)-2-hydroxy ester, followed by xanthate formation, pyrolytic elimination to form the cyclic olefin, and finally reduction of the carboxylic acid ester to yield ent-4. This compound is readily synthesized in 
high yield and in large quantities if desired (see the Supporting Information for details). To investigate the synthetic method outlined in Scheme 1, ent-4, which is much more readily accessible than $\mathbf{4 , 9}$ was used in the research described in this paper.

Protection of the alcohol as the $O$-silyl ether followed by oxidative ring opening and concomitant methyl esterification with the method of Marshall and Garafalo14 provided a mixture of mono- and diesters. Following treatment with $\mathrm{TMSCHN}_{2}$, diester 7 was obtained in $70 \%$ yield (Scheme 2 ). At this point, the strategy was to remove the silyl ether $(\mathbf{7} \rightarrow \mathbf{3})$ in order to incorporate various phosphorus functionalities, which would be converted to a nucleophilic reagent ( $\mathrm{P}^{\mathrm{III}}$ species, phosphorus anion, phosphorus radical) for construction of the second $\mathrm{P}-\mathrm{C}$ bond required in the synthesis of $\mathbf{1}$. To our surprise, treatment of $\mathbf{7}$ with TBAF resulted in a novel deprotection-rearrangement reaction to give $\mathbf{5}$ in $84 \%$ yield.

Formation of $\mathbf{5}$ can be rationalized by the mechanism shown in Scheme 3. Deprotection of the silyl protecting group results in formation of alkoxide $\mathbf{8}$, which attacks the $\gamma$-methyl ester to form lactone 9 and generate 1 equiv of methoxide anion. The methoxide anion then abstracts the acidic lactone methine proton, generating compound $\mathbf{1 0}$, which upon workup provides $\mathbf{5}$ in excellent yield. To our knowledge this is the first time that this type of rearrangement has been described in the literature.

While synthetic routes to both 2-methylene glutaric acid and the corresponding diesters are readily available,4,15-21 selective esterification of one of the two acids has been reported only rarely. 2-Methyleneglutaric acid 1-methyl ester, $\mathbf{5}$, has been reported in a mechanistic study on the photooxygenation of 2-methoxy-3-methyl-2-cyclopenen-1-one;22 however, the isolated yield was not reported and NMR analysis of the crude reaction indicates yields of less than $50 \%$ for the formation of $\mathbf{5}$. The corresponding a-ethyl ester has been reported in the patent literature via a lipase-catalyzed de-esterification of diethyl 2-methyleneglutarate. 23 The regioisomeric ester, 2-methyleneglutaric acid 5-methyl ester, has been prepared electrochemically by the addition of $\mathrm{CO}_{2}$ to pent-4-ynoic acid methyl ester in $38 \%$ yield; however, the free acid was not isolated. Instead, the product was converted to the dimethyl ester for isolation and purification.24 As reported in the patent literature, this regioisomer has also been synthesized via an iodine-mediated selective esterification of the nonconjugated carboxylic acid of 2-methyleneglutaric acid.25 We recently described an efficient synthesis of 2-methylene glutaric acid 5-tert-butyl ester through Michael addition of protected malonates to tert-butyl acrylate followed by a tandem Mannich reaction and in situ decarboxylation. 9

The efficient synthesis of $\mathbf{5}$ described herein uses an enantiomerically pure 3-substituted cyclopentene, ent-4, for the reasons described above. However, since the chirality at the stereogenic center is lost during the rearrangement to form $\mathbf{5}$, possible use of a racemic precursor, rac-4, that may be more readily available was investigated. In addition to the syntheses of rac-4 noted above, a low-yielding multistep synthesis of racemic rac-4 has been reported26 via $\mathrm{LAH}$ reduction of the corresponding carboxylic acid which, in turn, was generated from the addition of $\mathrm{CO}_{2}$ to the Grignard reagent of 3-chlorocyclopentene. In our hands, the yield of this Grignard reaction was extremely low. A higher yielding preparation of racemic rac-4 using Rieke magnesium has been reported,27 but the use of highly flammable Rieke magnesium for the large-scale preparation of $r a c-4$ is of concern. Since a search of the literature and our own experience did not produce an efficient synthesis of rac$\mathbf{4}$, the use of ent $\mathbf{4}$ as described (Scheme 2) is recommended.

Supporting Information Available: ${ }^{1} \mathrm{H}$ and ${ }^{13} \mathrm{C}$ NMR spectral data for compounds 5-7 and experimental procedures for the largescale synthesis of ent $\mathbf{4}$. This material is available free of charge via the Internet at http://pubs.acs.org. 
In summary, a concise 3-step synthesis of an a-protected methyleneglutarate $\mathbf{5}$ from easily prepared starting materials has been developed. This compound is a useful precursor for the synthesis of peptidomimetic compounds and may be useful as intermediates for synthesizing partially or fully reduced functionalities, i.e., aldehyde or alcohol, at the $\gamma$-position of 2methyleneglutarate.

\section{Experimental Section}

\section{General Experimental Procedures}

See the Supporting Information.

\section{(R)-1- tert-Butyldimethylsilyloxymethylcyclopent-2-ene, 6}

To a solution of ent-413 ( $0.9 \mathrm{~g}, 9.2 \mathrm{mmol})$ and TBDMSCl $(2.8 \mathrm{~g}, 18.4 \mathrm{mmol})$ in anhydrous DMF $(10 \mathrm{~mL})$ at room temperature under Ar was added imidazole $(3.1 \mathrm{~g}, 46 \mathrm{mmol})$ in one portion. The reaction was stirred at room temperature for $24 \mathrm{~h}$. The reaction was concentrated under reduced pressure $\left(2 \mathrm{mmHg}, 40^{\circ} \mathrm{C}\right)$ and the crude oil was partitioned between hexanes/Et $2 \mathrm{O}(1: 1,100 \mathrm{~mL})$ and saturated aqueous $\mathrm{NaHCO}_{3}(50 \mathrm{~mL})$. The aqueous layer was extracted with hexanes/ $\mathrm{Et}_{2} \mathrm{O}(1: 1,50 \mathrm{~mL})$ and the combined organic layers were washed with $\mathrm{H}_{2} \mathrm{O}(50 \mathrm{~mL})$. The organic layer was dried over $\mathrm{MgSO}_{4}$, filtered, and concentrated. The crude product was purified by silica gel chromatography (4:1 hexanes/ EtOAc) to give $1.8 \mathrm{~g}$ of 6 as a clear oil $(92 \%) .{ }^{1} \mathrm{H} \mathrm{NMR}\left(\mathrm{CDCl}_{3}\right) \delta 5.77(\mathrm{~m}, 1 \mathrm{H}), 5.69(\mathrm{~m}$, $1 \mathrm{H}), 3.48(\mathrm{~m}, 2 \mathrm{H}), 2.86(\mathrm{~m}, 1 \mathrm{H}), 2.30(\mathrm{~m}, 2 \mathrm{H}), 1.96(\mathrm{~m}, 1 \mathrm{H}), 1.52(\mathrm{~m}, 1 \mathrm{H}), 0.89(\mathrm{~s}, 9 \mathrm{H})$, $0.07(\mathrm{~s}, 6 \mathrm{H}) .{ }^{13} \mathrm{C} \mathrm{NMR}\left(\mathrm{CDCl}_{3}\right) \delta 132.5,132.0,67.4,48.9,32.0,26.3,26.1,18.5,-5.1 . \mathrm{MS}$ (ESI) $\mathrm{m} / z 212.2\left([\mathrm{M}+\mathrm{H}]^{+}, 100\right)$. HRMS (ESI) calcd for $\mathrm{C}_{12} \mathrm{H}_{24} \mathrm{OSi} 212.1596[\mathrm{M}+\mathrm{H}]^{+}$, found 212.1593 .

\section{(R)-2-(tert-Butyldimethylsilyloxymethyl)pentanedioic Acid Dimethyl Ester, 7}

Ozone was bubbled through a solution of $6(1.0 \mathrm{~g}, 4.7 \mathrm{mmol})$ in $2.5 \mathrm{M} \mathrm{NaOH}$ in $\mathrm{MeOH}(10$ $\mathrm{mL})$ and $\mathrm{CH}_{2} \mathrm{Cl}_{2}(40 \mathrm{~mL})$ at $-78{ }^{\circ} \mathrm{C}$ until a persistent blue color of excess ozone was observed. $\mathrm{O}_{2}$ was bubbled through the solution for $20 \mathrm{~min}$ to purge the excess ozone. The reaction was allowed to warm to room temperature and was partitioned between diethyl ether $(25 \mathrm{~mL})$ and $\mathrm{H}_{2} \mathrm{O}(25 \mathrm{~mL})$. The aqueous layer was extracted with diethyl ether $(3 \times 25$ $\mathrm{mL})$. The organic layer was concentrated and the crude oil was taken up in EtOAc $(25 \mathrm{~mL})$, dried over $\mathrm{Na}_{2} \mathrm{SO}_{4}$, filtered, and concentrated. The resulting clear oil was dissolved in $\mathrm{MeOH}(10 \mathrm{~mL})$, cooled to $0{ }^{\circ} \mathrm{C}$, and treated with $\mathrm{TMSCHN}_{2}$ until a persistent yellow color was observed. The ice bath was removed and the reaction was stirred at room temperature for $15 \mathrm{~min}$, then quenched with $\mathrm{AcOH}$ and concentrated. The crude product was purified by silica gel chromatography ( $4: 1$ hexanes/EtOAc) to give $0.98 \mathrm{~g}$ of 7 as a clear oil $(70 \%) .{ }^{1} \mathrm{H}$ $\operatorname{NMR}\left(\mathrm{CDCl}_{3}\right) \delta 3.77(\mathrm{~m}, 2 \mathrm{H}), 3.68(\mathrm{~s}, 3 \mathrm{H}), 3.67(\mathrm{~s}, 3 \mathrm{H}), 2.61(\mathrm{~m}, 1 \mathrm{H}), 2.36(\mathrm{~m}, 2 \mathrm{H}), 1.90$ (m, 2H), 0.89 (s, 9H), 0.07 (s, 6H). ${ }^{13} \mathrm{C} \mathrm{NMR}\left(\mathrm{CDCl}_{3}\right) \delta 174.4,173.6,64.0,51.75,51.72$, 47.7, 31.8, 25.9, 23.7, 18.3, -5.4. MS (ESI) $\mathrm{m} / \mathrm{z} 304.2$ ([M + H $\left.]^{+}, 100\right)$. HRMS (ESI) calcd for $\mathrm{C}_{14} \mathrm{H}_{28} \mathrm{O}_{5} \mathrm{Si} 304.1706[\mathrm{M}+\mathrm{H}]^{+}$, found 304.1704.

\section{2-Methylenepentanedioic Acid 1-Methyl Ester ( $\alpha$-Methyl 2-Methyleneglutarate), 5}

To a solution of $7(0.75 \mathrm{~g}, 2.5 \mathrm{mmol})$ in anhydrous THF $(10 \mathrm{~mL})$ at $0{ }^{\circ} \mathrm{C}$ was added TBAF $(3.8 \mathrm{~mL}, 3.8 \mathrm{mmol})$. The reaction was allowed to warm to room temperature and stirred for $2 \mathrm{~h}$. The reaction was concentrated and the crude oil was portioned between EtOAc $(50 \mathrm{~mL})$ and $1 \%$ aq $\mathrm{HCl}(10 \mathrm{~mL})$. The organic layer was dried over $\mathrm{Na}_{2} \mathrm{SO}_{4}$, filtered, and concentrated. The crude product was purified by silica gel chromatography (1:1 hexanes/ EtOAc then $100 \%$ EtOAc) to give $0.33 \mathrm{~g}$ of $\mathbf{5}$ as a clear oil $(84 \%) .{ }^{1} \mathrm{H}$ NMR $\left(\mathrm{CDCl}_{3}\right) \delta 9.41$ (br s, 1H), $6.21(\mathrm{~d}, 1 \mathrm{H}, J=1.1 \mathrm{~Hz}), 5.62(\mathrm{~d}, 1 \mathrm{H}, J=1.1 \mathrm{~Hz}), 3.75(\mathrm{~s}, 3 \mathrm{H}), 2.63$ to 2.53 
(overlapping $\mathrm{m}, 4 \mathrm{H}) .{ }^{13} \mathrm{C} \mathrm{NMR}\left(\mathrm{CDCl}_{3}\right) \delta 178.8,167.2,138.6,126.3,52.1,33.0,27.1 . \mathrm{MS}$ $\left(\mathrm{CI} / \mathrm{NH}_{3}\right) \mathrm{m} / \mathrm{z} 159.1\left([\mathrm{M}+\mathrm{H}]^{+}, 100\right)$. HRMS $\left(\mathrm{CI} / \mathrm{NH}_{3}\right)$ calcd for $\mathrm{C}_{7} \mathrm{H}_{11} \mathrm{O}_{4} 159.1623[\mathrm{M}+$ $\mathrm{H}]^{+}$, found 159.0656 .

\section{Acknowledgments}

This research was supported by a grant from the National Cancer Institute (CA28097). D.M.B. is a trainee in the Pharmacological Sciences Training Program supported by a grant from the National Institutes of General Medical Sciences (GM07767). We thank Matthew Alexander for helpful discussions concerning the reactions depicted in Scheme 3 and Debatosh Majumdar for providing a sample of an ester precursor of ent-4. The authors also thank Craig A. Townsend and The Johns Hopkins University for providing the use of their facilities to complete this research.

\section{Supplementary Material}

Refer to Web version on PubMed Central for supplementary material.

\section{References}

(1). Wolinsky J, Novak R, Vasileff R. J. Org. Chem. 1964; 29:3596-3598.

(2). Wender PA, Schaus JM, White AW. J. Am. Chem. Soc. 1980; 102:6159-6161.

(3). Nicolaou KC, Gray D. Angew. Chem., Int. Ed. 2001; 40:761-763.

(4). Jackson PF, Tays KL, Maclin KM, Ko Y, Li W, Vitharana D, Tsukamoto T, Stoermer D, Lu XM, Wozniak K, Slusher BS. J. Med. Chem. 2001; 44:4170-4175. [PubMed: 11708918]

(5). Liu X, Hu E, Tian X, Mazur A, Ebetino FH. J. Organomet. Chem. 2002; 646:212-222.

(6). Yiotakis A, Georgiadis D, Matziari M, Makaritis A, Dive V. Curr. Org. Chem. 2004; 8:11351158.

(7). Hatada K, Kitayama T, Ute K. Prog. Polym. Sci. 1988; 13:189-276.

(8). Valiaeva N, Bartley D, Konno T, Coward JK. J. Org. Chem. 2001; 66:5146-5154. [PubMed: 11463268]

(9). Bartley DM, Coward JK. J. Org. Chem. 2005; 70:6757-6774. [PubMed: 16095295]

(10). Tsukamoto T, Flannery J, Rojas C, Slusher BS, Valiaeva N, Coward JK. Bioorg. Med. Chem. Lett. 2002; 12:2189-2192. [PubMed: 12127534]

(11). Hanack M, Schneider HJ. Tetrahedron. 1964; 20:1863-1879.

(12). Colombini M, Crotti P, Di Bussolo V, Favero L, Gardelli C, Macchia F, Pineschi M. Tetrahedron. 1995; 51:8089-8112.

(13). Maeda K, Inouye Y. Bull. Chem. Soc. Jpn. 1994; 67:2880.

(14). Marshall JA, Garofalo AW. J. Org. Chem. 1993; 58:3675-3680.

(15). Shabtai J, Hey-Igner E. J. Org. Chem. 1978; 43:4186-4090.

(16). Amri H, Rambaud M, Villieras J. Tetrahedron Lett. 1989; 30:7381-7382.

(17). Drewes SE, Emslie ND, Karodia N. Synth. Commun. 1990; 20:1915-1921.

(18). Jackson PF, Cole DC, Slusher BS, Stetz SL, Ross LE, Donzanti BA, Trainor DA. J. Med. Chem. 1996; 39:619-622. [PubMed: 8558536]

(19). Brase S, Waigell B, de Meijere A. Synthesis. 1998; 2:148-152.

(20). Yi CS, Liu N. J. Organomet. Chem. 1998; 553:157-161.

(21). Jenner G. Tetrahedron Lett. 2000; 41:3091-3094.

(22). Kwon B-M, Foote CS. J. Org. Chem. 1989; 54:3878-3882.

(23). Yamauchi, Y. Japanese Patent. 06228053. 1994.

(24). Dunach E, Perichon J. Synlett. 1990; 3:143-145.

(25). Mitusbishi Petrochemical Co. Ltd. Japanese Patent. 59152347. 1984.

(26). Coe DM, Parry DM, Roberts SM, Storer R. J. Chem. Soc., Perkins Trans. 1. 1991; 10:23732377.

(27). Chapman OL, Mattes KC, Sheridan RS, Klun JA. J. Am. Chem. Soc. 1978; 100:4878-4884. 
<smiles>[R20]OC(=O)CCC(=C)C(=O)O[R6]</smiles><smiles>C=C</smiles><smiles>OC[C]1C=CCC1</smiles>

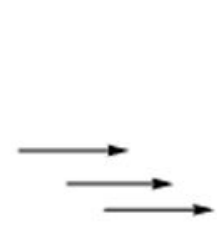<smiles>C=C(CCC(=O)O)C(=O)O[Na]</smiles>

4

5

SCHEME 1. 

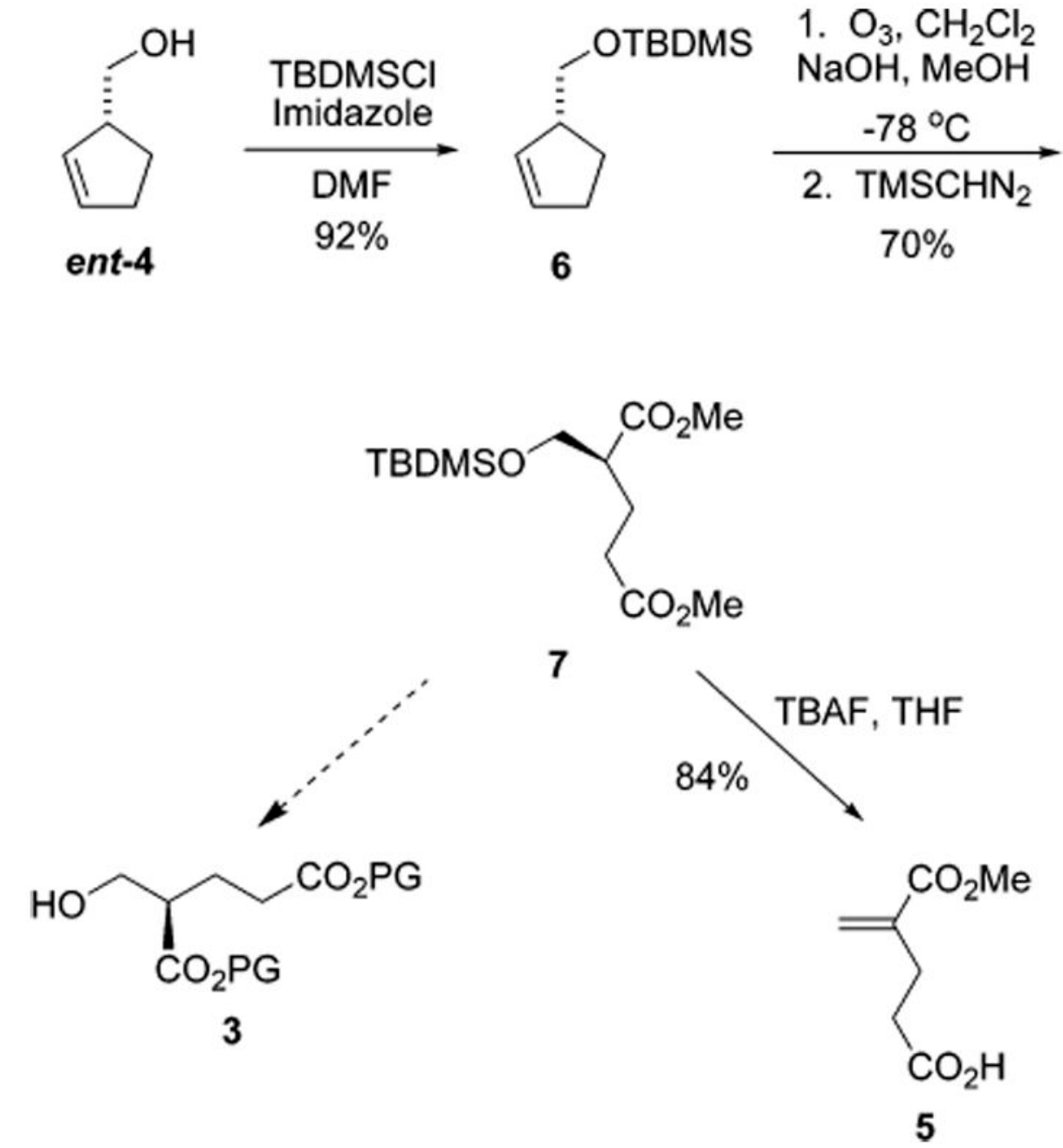

SCHEME 2. 

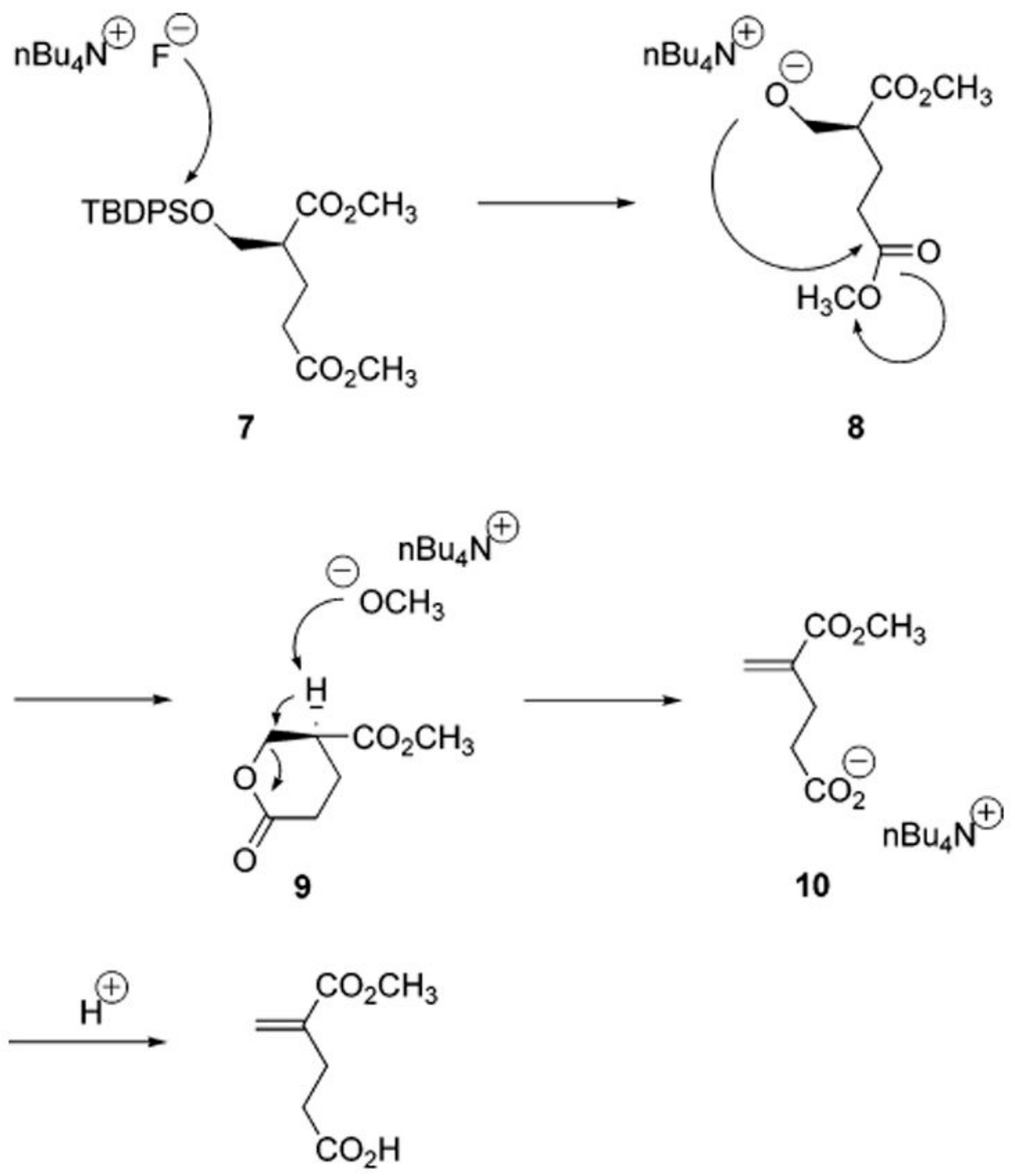

5

SCHEME 3. 